\title{
A Simple Sample Processing Protocol and Multiplex PCR for Direct Detection of MRSA from Uncultured Clinical Samples-A Pilot Study
}

\author{
Rosy Chikkala1, Swathi Ch1', Sireesha Divyakolu1, Kamaraju Suguna Ratnakar², \\ Venkataraman Sritharan ${ }^{1 *}$ \\ ${ }^{1}$ Molecular Diagnostics and Biomarkers Laboratory, Global Medical Education and Research Foundation, Hyderabad, India \\ ${ }^{2}$ Global Medical Education and Research Foundation, Hyderabad, India \\ Email: *venkataraman.sritharan@gmail.com
}

How to cite this paper: Chikkala, R., Ch, S., Divyakolu, S., Ratnakar, K.S. and Sritharan, V. (2019) A Simple Sample Processing Protocol and Multiplex PCR for Direct Detection of MRSA from Uncultured Clinical Samples-A Pilot Study. $A d$ vances in Infectious Diseases, 9, 25-38. https://doi.org/10.4236/aid.2019.91003

Received: February 5, 2019

Accepted: March 4, 2019

Published: March 7, 2019

Copyright $\odot 2019$ by author(s) and Scientific Research Publishing Inc. This work is licensed under the Creative Commons Attribution International License (CC BY 4.0).

http://creativecommons.org/licenses/by/4.0/

\begin{abstract}
Phenotypic tests have limited discrimatory power to identify closely related members of genus Staphylococcus and particularly for identification of $S$. aureus. 157 isolates of $S$. aureus obtained from different clinical specimens were included in our study. To present a demonstration of our method's sensitivity and ability to correctly detect $S$. aureus from uncultured clinical specimen, 30 known $S$. aureus positive but leftover uncultured clinical specimens from clinical microbiology laboratory were processed by our protocol and analyzed. All the 30 clinical specimens were confirmed as $S$. aureus among which 26 specimen were identified as MRSA and the remaining 4 as MSSA. These 30 clinical specimens used in the study showed $100 \%$ correlation with coagulase test and Cefoxitin disc diffusion method. Though commercial molecular diagnostic kits are available for detecting MRSA from swabs, this is probably the first time that multiplex PCR is being demonstrated directly on a variety of uncultured clinical specimens.
\end{abstract}

\section{Keywords}

mecA, nuc, Multiplex PCR, $S$. aureus

\section{Introduction}

$S$. aureus is a common pathogen causing minor skin infections to major life threatening diseases such as osteomyelitis, pneumonia and septicaemia [1] [2]. Accurate and rapid identification of $S$. aureus and MRSA directly from clinical samples is essential for the proper management of patients with bacteraemia, 
endocarditis, skin infections, abscesses, gastroenteritis, endocarditis, toxic shock syndrome and certain food toxicity [3] [4] [5]. In developing countries, phenotyping tests are mainstay in the diagnosis of staphylococcal infections and among them the coagulase test is usually confirmatory for $S$. aureus [6] [7] [8]. Although these tests efficiently identify $\mathcal{S}$. aureus, their performance varies from setting to setting resulting in variable reliability and reproducibility [4] [6]. The genus Staphylococcus contains more than 50 species and 30 subspecies which are widespread in nature [9] [10]. Three of them are important human pathogens: 1) $S$. aureus, which causes various pyogenic infections like endocarditis, osteomyelitis, skin and soft tissue infections, toxin-mediated diseases such as food poisoning, toxic shock syndrome and the scalded skin syndrome, 2) S. epidermidis, a member of the common skin flora, which causes infections associated with devices, such as catheters and prosthetics and 3) S. saprophyticus, which causes urinary tract infections [11]. Single phenotypic tests are inefficient for the identification of $S$. aureus. Indeed, mannitol salt agar (MSA) positive CoNS (Staphylococcus caprae, S. hemolyticus and S. saprophyticus) have been reported in Nigeria and Japan [12] [13]. However, a combination of methods like isolation on MSA and screening by DNase agar improves the outcome [14]. Thus, in certain settings, if used individually to identify Staphylococcus aureus, common phenotypic tests may be inconclusive; some isolates will be misidentified. The use of MSA prior to tube coagulase/DNase is highly recommended due to the clumping factor negative and tube coagulase positive Staphylococci that are increasingly being recovered from human infections [15]. These isolates also produce a heat stable DNase and can be misidentified as $S$. aureus. However, these strains can be differentiated from $S$. aureus by their failure to produce acid from maltose, lactose and mannitol. Furthermore, rare strains of $S$. aureus can be coagulase negative, some Staphylococcus isolates from animals (S. intermedius, S. hyicus, S. delphini and $S$. schleiferi subsp. coagulans) are clumping factor negative but tube coagulase positive [16] [17] differentiation of which requires isolation on MSA also.

Methicillin resistance in Staphylococci is conferred by mecA gene that produces altered PBP2a. Detection of mecA gene remains the gold standard for identification of methicillin resistance; however it does not confirm the species $S$. aureus [18]. There is no consensus on the genomic target that could be used to confirm the $S$. aureus. A number of auxiliary factors which influence methicillin resistance by regulating cell wall metabolism have been used by different laboratories to identify $\mathcal{S}$. aureus. Notable among them are the femA or femB and femX (factor essential for methicillin resistance) genes [19] [20]. However, failure to confirm the species of $S$. aureus as reported by others earlier [19] [21] [22] and our own report downplays the reliability of $f e m A$ or $f e m B$ as genomic target in species identification [23]. The exact reason for the false negative results with fem genotyping is not yet known.

The speed with which MRSA is detected has a significant role to play in any successful strategy to impede the pathogen from dissemination. Since MRSA detection by culture requires 2 - 3 days, quick detection techniques using PCR 
methods have made headway. The execution of these rapid tests minimizes the time of detection of MRSA from 48 - 72 [24] to 2 - $5 \mathrm{~h}$ [25] [26]. Clinical evaluation data have shown that MRSA can thus be detected with very high sensitivity. Currently there are commercial kits which can only detect MRSA (S. aureus) from nasal swabs and positive blood cultures. Presently available molecular tests which are PCR based for MRSA detection include the HyplexStaphyloResist PCR (BAG, Lich, Germany), the GenoType MRSA direct assay (Hain Lifescience, Germany), LightCycler Staphylococcus and MRSA detection kit (LC assay; Roche Diagnostics, Germany), the IDI-MRSA assay (GenOhm, San Diego, BD Diagnostics), and the recently introduced GeneXpert MRSA assay (Cepheid, Sunnyvale). Rossney et al. [26] evaluated Xpert MRSA assay, which is run on the GeneXpert real-time PCR platform (Cepheid) for clinical samples like swabs from nose, throat, and groin/perineum sites. $90 \%$ Sensitivity and $97 \%$ specificity was reported for clinical specimens from all sites, but for throat specimens they reported poor sensitivity of $75 \%$. Boyce et al. compared BD GeneOhm (MRSA) real-time PCR assay formerly called IDI-MRSA with CHROM agar MRSA assay. BD GeneOhm PCR assay had sensitivity of $100 \%$ and specificity of $98.5 \%$ with a turn-around time of $14.5 \mathrm{~h}$ [25]. Levi et al. evaluated LC Staphylococcus assay on pooled patient screening swabs which showed $90.8 \%$ specificity and $95.7 \%$ sensitivity [27]. All these kits which could detect MRSA rapidly and were easy to use had major limitations like being very expensive, could be performed only in swabs of nasal, groin and blood samples and results need to be compared with culture. In addition, the Xpert MRSA assay requires more interpretation than currently suggested by the manufacturer therefore more expertise is required. Table 1 shows the kits used in MRSA identification and their limitations in detail. It may be noted that many of these kits are not validated on clinical samples other than swabs. In this study we used nuc gene as genetic marker for PCR amplification to identify clinical isolates of $S$. aureus in comparison to some of the conventional phenotyping methods. We also designed a simple sample processing protocol and multiplex PCR using nuc as species marker instead of fem sequence. We have demonstrated in this study the potential of the sample processing protocol and multiplex PCR on 30 uncultured left over but characterised clinical samples as a pilot study.

\section{Materials \& Methods}

\subsection{Culture Isolation and Characterization}

157 isolates of $S$. aureus obtained from different clinical specimens were included in our study. $S$. aureus colonies were identified by standard microbiological tests which included isolation on mannitol salt agar, coagulase test and DNase test. All $S$. aureus isolates were screened with Cefoxitin $(30 \mu \mathrm{g})$ and $\mathrm{Ox}$ acillin $(1 \mu \mathrm{g})$ disc on Mueller Hinton Agar to identify MRSA and MSSA. Thermonuclease activity was measured by streaking isolates on Methyl Green DNase Agar (Himedia Pvt Ltd) plates, and measure the zone of clearance after $24 \mathrm{~h}$ at $37^{\circ} \mathrm{C}$. 
Table 1. Comparison of commercial MRSA detection kits.

\begin{tabular}{|c|c|c|c|c|c|c|}
\hline Kit Name & Company & Specimen & Target Genes & Time & Comments & References \\
\hline IDI-MRSA $^{\mathrm{T \mu}}$ Assay & $\begin{array}{l}\text { Infection } \\
\text { Diagnostic } \\
\text { (I.D.I.) Inc }\end{array}$ & $\begin{array}{l}\text { Nasal Swabs \& } \\
\text { Isolated Colonies }\end{array}$ & $\begin{array}{l}\text { orfX sequence and a } \\
\text { sequence of } \\
\text { SCCmec near the } \\
\text { integration site }\end{array}$ & $48 \mathrm{~h}$ & $\begin{array}{l}\text { 1) Only for nasal swabs and culture isolates. } \\
\text { 2) US FDA approved. }\end{array}$ & [36] \\
\hline $\begin{array}{l}\text { Real MRSA and Real } \\
\text { MRCONS multiplex } \\
\text { real time PCR assay } \\
\text { kit }\end{array}$ & $\begin{array}{l}\text { M and D, } \\
\text { Wonju, } \\
\text { Republic of } \\
\text { Korea }\end{array}$ & $\begin{array}{l}\text { Culture isolates } \\
\text { and Blood culture }\end{array}$ & $\begin{array}{l}16 \mathrm{~S} \text { rRNA, nuc and } \\
\text { mecA }\end{array}$ & $4 \mathrm{~h}$ & $\begin{array}{l}\text { 1) Wang et al reported false negative results } \\
\text { due to the presence of PCR inhibitors or } \\
\text { polymicrobial infections in direct blood samples } \\
\text { 2) Expensive }\end{array}$ & [37] \\
\hline $\begin{array}{l}\text { BacLite Rapid MRSA } \\
\text { Test }\end{array}$ & $\begin{array}{l}3 \mathrm{M} \\
\text { Company }\end{array}$ & Nasal swabs & $\begin{array}{l}\text { Adenylate Kinase } \\
\text { activity }\end{array}$ & $5 \mathrm{~h}$ & $\begin{array}{l}\text { 1) This company claimed that swabs are } \\
\text { confirmed negative in } 5 \mathrm{~h} \text { and positives the next } \\
\text { day } \\
\text { 2) It uses Bioluminescence combined, a } \\
\text { sensitivity } 94.6 \% \text { and specificity } 99 \% \text {. } \\
\text { 2) Evaluated only in nasal swabs and inguinal } \\
\text { swabs. } \\
\text { 3) Johnson et al. reported false positives due to } \\
\text { the presence of MRCON and a sensitivity of } \\
90.4 \% \text { and specificity of } 95 \% \text {. }\end{array}$ & [38] \\
\hline $\begin{array}{l}\text { HyplexStaphyloResist } \\
\text { PCR Enzyme Linked } \\
\text { Immunosorbent assay }\end{array}$ & $\begin{array}{l}\text { BAG, Lich, } \\
\text { Germany }\end{array}$ & $\begin{array}{l}\text { Nasal, Throat, } \\
\text { Perineum and } \\
\text { wound Swabs }\end{array}$ & $\begin{array}{l}\text { mecA, Coagulase } \\
\text { gene and nuc }\end{array}$ & $6 \mathrm{~h}$ & $\begin{array}{l}\text { 1) Coagulase gene polymorphism has been } \\
\text { reported. } \\
\text { 2) False positives were reported } \\
\text { 3) Only for swabs. }\end{array}$ & [39] \\
\hline $\begin{array}{l}\text { REBA Sepsis -ID Test } \\
\text { PCR Reverse Blot } \\
\text { Hybridization Assay }\end{array}$ & Optipharm & $\begin{array}{l}\text { Blood Culture } \\
\text { Bottles }\end{array}$ & $\begin{array}{l}m e c A, \operatorname{van} A \text { and } \\
\operatorname{vanB}\end{array}$ & $4 \mathrm{~h}$ & $\begin{array}{l}\text { 1) This kit distinguishes Gram-positive bacteria, } \\
\text { Gram-negative bacteria and fungi using } \\
\text { pan-probes and antibiotic resistance genes. As } \\
\text { well as identifies MRSA and VRE. As claimed by } \\
\text { Optiparm. } \\
\text { 2) Used as Diagnostic tool as well as for research } \\
\text { for detection of several pathogens } \\
\text { 3) Park SD reportedthat no specific probes for } \\
\text { extended-spectrum } \beta \text {-lactamases and } \\
\text { carbapenemases for the detection of } \\
\text { antibiotic-resistant GNB. } \\
\text { 4) No IVD certification } \\
\text { 5) Detects only in blood culture bottles } \\
\text { 6) Wang HY reported of false negatives. }\end{array}$ & {$[40][41]$} \\
\hline Xpert MRSA assay & $\begin{array}{l}\text { Cepheid, } \\
\text { Sunnyvale, } \\
\text { CA, USA }\end{array}$ & $\begin{array}{l}\text { Lower-respiratory- } \\
\text { tract specimens, } \\
\text { Nasal swabs and } \\
\text { blood cultures }\end{array}$ & $\begin{array}{l}\text { MRSA-specific } \\
\text { DNA sequence } \\
\text { within the SCCmec }\end{array}$ & $2 \mathrm{~h}$ & $\begin{array}{l}\text { 1) Cepheid claimed that this kit can't be used for } \\
\text { all types of specimens. } \\
\text { 2) Oh A-C et al. reported false negatives and false [ } \\
\text { positives } \\
\text { 3) US FDA approved }\end{array}$ & {$[42]$} \\
\hline $\begin{array}{l}\text { Hain GenoQuick } \\
\text { (GQM) methicillin } \\
\text { resistant } \\
\text { Staphylococcus } \\
\text { aureus (MRSA) assay }\end{array}$ & $\begin{array}{l}\text { Hain Life } \\
\text { science }\end{array}$ & $\begin{array}{l}\text { Nasal and groin } \\
\text { swabs }\end{array}$ & $\begin{array}{l}\text { MRSA-specific } \\
\text { chromosomal } \\
\text { sequences }\end{array}$ & $2.5 \mathrm{~h}$ & $\begin{array}{l}\text { 1) Only Nasal and groin swabs can be processed. } \\
\text { 2) IVD approved. }\end{array}$ & [43] \\
\hline $\begin{array}{l}\text { Light Cycler MRSA } \\
\text { advanced test }\end{array}$ & Roche & Nasal Swabs & $\begin{array}{l}\text { orfX sequence } \\
\text { and a sequence of } \\
\text { SCCmec near the } \\
\text { integration site }\end{array}$ & $3 \mathrm{~h}$ & $\begin{array}{l}\text { 1) } m e c A \text { gene is present in many other Coagulase } \\
\text { negative Staphylococcal species, thereby causing } \\
\text { false identification. } \\
\text { 2) W C Yam et al. evaluated this kit and reported } \\
83.3 \% \text { sensitivity and } 99 \% \text { specificity. } \\
\text { 3) Detects only in nasal swabs which is a major } \\
\text { drawback. } \\
\text { 4) IVD and US FDA Approved }\end{array}$ & [44] [45] \\
\hline
\end{tabular}




\section{Continued}

\begin{tabular}{|c|c|c|c|c|c|c|}
\hline $\begin{array}{l}\text { QX100 droplet digital } \\
\text { PCR system }\end{array}$ & Bio-Rad & $\begin{array}{l}\text { Nasal Swabs and } \\
\text { isolated colonies }\end{array}$ & $\begin{array}{l}\text { mecA and SA } 0140 \\
\text { protein gene }\end{array}$ & $48 \mathrm{~h}$ & $\begin{array}{l}\text { 1) Expensive } \\
\text { 2) Specific equipment for DNA extraction and } \\
\text { sample processing is required. } \\
\text { 3)Not IVD approved }\end{array}$ & {$[46]$} \\
\hline $\begin{array}{l}\text { BDMaxStaphSR } \\
\text { assay kit }\end{array}$ & $\begin{array}{l}\text { Becton- } \\
\text { Dickinson }\end{array}$ & Nasal Swabs & $\begin{array}{l}\text { mecA / mecC, nuc } \\
\text { and orfX sequence }\end{array}$ & $4 \mathrm{~h}$ & $\begin{array}{l}\text { 1) Only Nasal swabs can be processed. } \\
\text { 2) False negatives were reported. } \\
\text { 3) US FDA approved } \\
\text { 4) Used for diagnostic purpose }\end{array}$ & [47] [48] \\
\hline $\begin{array}{l}\text { MRSA/SA } \\
\text { ELITe MGB }\end{array}$ & $\begin{array}{l}\text { EliTech } \\
\text { Molecular } \\
\text { Diagnostics }\end{array}$ & $\begin{array}{l}\text { Nasal Swabs and } \\
\text { blood cultures }\end{array}$ & $\begin{array}{l}\text { mecA } / \text { mecC, } \\
\text { Species specific } \\
\text { marker and } 16 \mathrm{~s} \\
\text { rRNA }\end{array}$ & $5 \mathrm{~h}$ & $\begin{array}{l}\text { 1) Only nasal swabs can be processed. } \\
\text { 2) IVD and US FDA approved }\end{array}$ & {$[35]$} \\
\hline $\begin{array}{l}\text { BD GeneOhm } \\
\text { MRSA Assay }\end{array}$ & $\begin{array}{l}\mathrm{BD} \\
\text { Diagnostics }\end{array}$ & $\begin{array}{l}\text { Nasal and } \\
\text { non-nasal swabs } \\
\text { only }\end{array}$ & orfX sequences & $2 \mathrm{~h}$ & $\begin{array}{l}\text { 1) US FDA approved for direct detection in } \\
\text { nasal swabs. } \\
\text { 2) Katja Lucke et al. reported } 84.3 \% \text { sensitivity } \\
\text { and } 99.2 \% \text { specificity. } \\
\text { 4) False negative results due to sequence } \\
\text { variations } \\
\text { 5) IVD approved. }\end{array}$ & [49] [50] \\
\hline $\begin{array}{l}\text { Duplex Light } \\
\text { Cycler PCR Assay }\end{array}$ & Roche & Bacterial colonies & $\begin{array}{l}\text { mecA and SA442 } \\
\text { species specific } \\
\text { marker }\end{array}$ & $26 \mathrm{~h}$ & Only for culture confirmation & {$[51]$} \\
\hline TEX Method & & $\begin{array}{l}\text { Uncultured } \\
\text { Clinical Samples }\end{array}$ & $\begin{array}{l}\text { mecA, } 16 \mathrm{~S} \text { rRNA, } \\
\text { and nuc }\end{array}$ & $5 \mathrm{~h}$ & $\begin{array}{l}\text { 1) Rules-in or rules-out S. aureus and non-S. } \\
\text { aureus species } \\
\text { 2) Universal, simple and affordable sample } \\
\text { processing protocol for PCR DNA target } \\
\text { preparation. } \\
\text { 3) Not commercially available yet. }\end{array}$ & [29] \\
\hline
\end{tabular}

\subsection{Genotyping of Clinical Isolates of $S$, aureus}

DNA was isolated [28] from a few isolates of $S$. aureus for initial optimization of PCR, precipitated with isopropanol and finally dissolved in $10 \mathrm{mM}$ Tris-EDTA buffer (pH8.0). For subsequent screening of all the isolates, cell free DNA lysate was prepared by TEX (Tris buffer pH 8.0-EDTA-Triton X-100) method [29] Primers and the thermal cycling conditions are detailed out in Table 2. Staphylococcus genus was confirmed with 16S rRNA [30] and MRSA was confirmed by the detection of mecA [31] while nuc was evaluated as genomic target for species identification [32] [33] against microbiology methods.

\subsection{Processing Uncultured Specimens}

A total of 30 clinical specimens confirmed to contain $S$. aureus including swabs, endotracheal secretions and pus samples collected from Microbiology laboratory. These were the left over samples and collected after $24 \mathrm{~h}$ of storage at $4^{\circ} \mathrm{C}$. All of them were processed by the TEX method and the DNA lysates were stored at $-20^{\circ} \mathrm{C}$ until use. The flowchart of processing the samples is as shown in the scheme Figure 1. 
Table 2. Primers used for study.

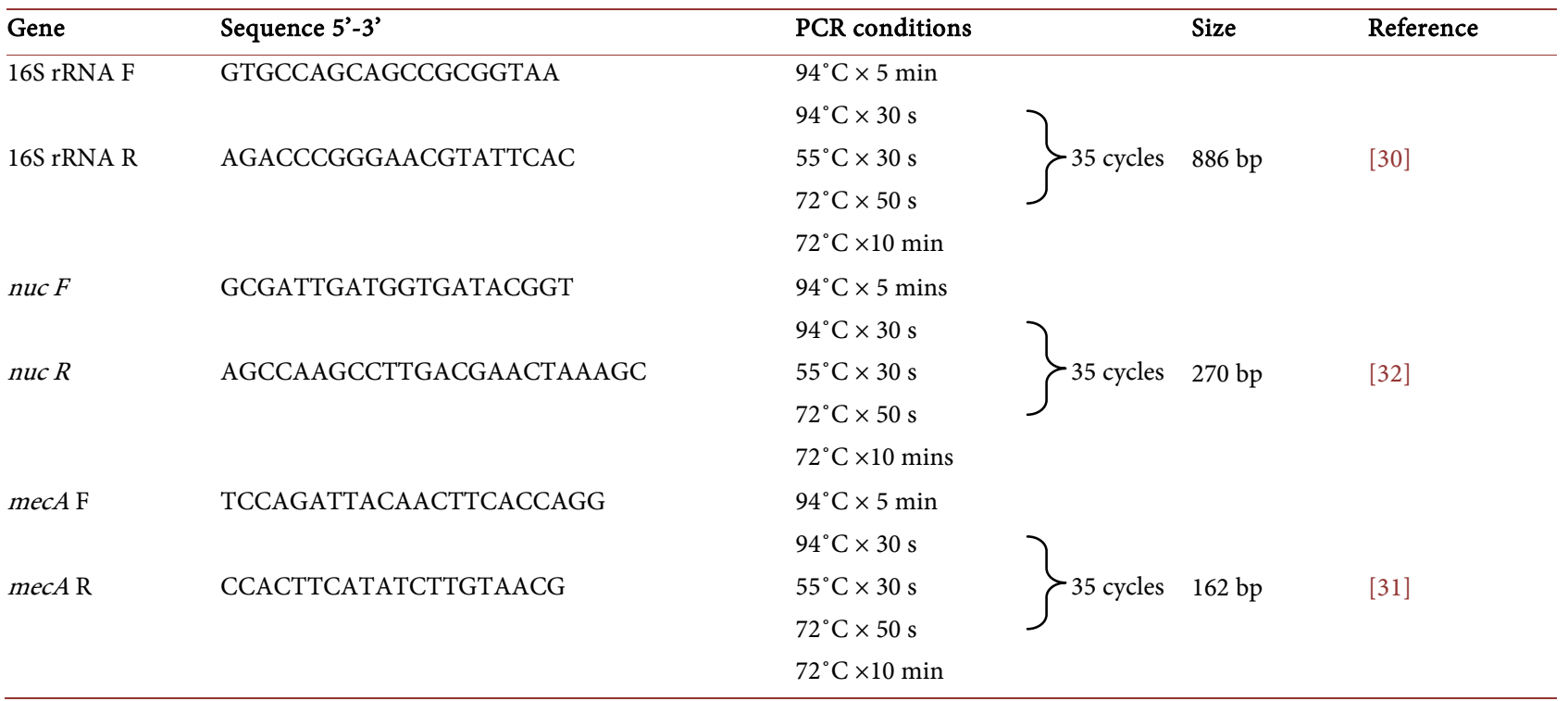

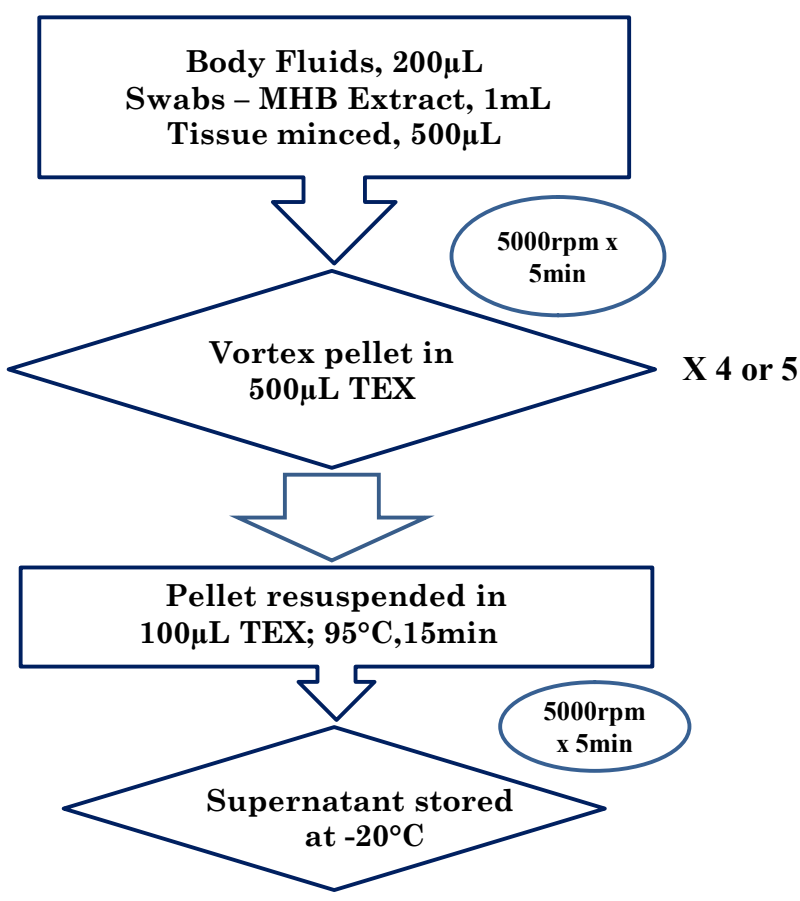

Figure 1. Flow chart for processing of uncultured clinical samples.

Three sets of primers were used, one for nuc (species specific gene), one for $16 \mathrm{~S}$ rRNA (genus specific gene) and another one for mecA (methicillin resistance gene). The reaction conditions for the multiplex PCR are described in Table 1 . The PCR reaction mixture in a volume of $20 \mu \mathrm{L}$ contained the following; $1.5 \mathrm{mM} \mathrm{MgCl}_{2}, 30 \mathrm{pmol}$ of each primer of mecA and nuc, $10 \mathrm{pmol}$ of primers of $16 \mathrm{~S}$ rRNA, $200 \mu \mathrm{mol}$ of dNTP along with $1 \mathrm{U}$ of Taq (KAPA Taq DNA Polymerase, KAPA Biosystems Inc.) and $10 \mu \mathrm{L}$ of cell free lysate as DNA template. $S$. aureus ATCC 6538P was used as positive control MRSA (PC). Other gram posi- 
tive and gram negative ATCC cultures were used to check the specificity of our multiplex PCR (NC). Gram positive ATCC cultures included ATCC 27626 Staphylococcus epidermidis, ATCC 6305 Streptococcus pnuemoniae, ATCC 29212 Enterococcus faecalis, and ATCC 700221 Enterococcus faecium. Gram negative ATCC cultures comprised of ATCC 19606 Acinetobacter baumanii, ATCC 10418 E. coli, ATCC 70060 Klebsiella pneumoniae, ATCC 13048 Enterobacter aerogenes.

\section{Results}

All isolates were screened and confirmed by coagulase test. 157 coagulase positive isolates were included as $S$. aureus in this study. We screened these isolates for methicillin resistance (MRSA) by Cefoxitin and Oxacillin Disc diffusion test, 105 isolates were MRSA and 52 were MSSA. However, in genotyping, 106 isolates were identified as MRSA ( $m e c A-P C R$ positive) and the remaining 51 isolates were classified as MSSA ( $m e c A$-PCR negative). One isolate which was indeterminate $(22 \mathrm{~mm})$ by Cefoxitin disc method was found to harbour mecA. The Oxacillin disc diffusion test did not compare well with mecA PCR test; 67\% sensitivity, $94 \%$ specificity, $96 \%$ positive predictive value (PPV) and $58 \%$ negative predictive value (NPV). Cefoxitin disc diffusion test compared well with mec $A$ PCR with sensitivity of $99.06 \%$, specificity $100 \%$, Positive Predictive Value of $100 \%$; and a Negative Predictive Value of $98 \%$. The results are presented in Table 3(a) and Table 3(b).

\subsection{Genotyping of Cultured $S$, aureus $(\mathrm{n}=157)$}

We used only coagulase positive isolates and found thermonuclease gene reliable for $S$. aureus detection from our previous study [23] hence we used thermonuclease nuc gene for $S$. aureus detection from uncultured clinical samples. The sensitivity of nuc PCR were 95\% (149/157) respectively (Figure 2). We used Medcalc software (MedCalc Statistical Software version 15.6.1, MedCalc Software, Ostend, Belgium; https://www.medcalc.org; 2015) for statistical analysis.

\subsection{Genotyping of $S$, aureus $(\mathrm{n}=30)$ from Uncultured Clinical Specimen}

We optimised a triplex PCR for detection of mecA, nuc and 16S rRNA with 31 uncultured left over specimen from microbiology laboratory. This multiplex PCR produced distinct amplicons of expected size for mecA (162 bp), nuc (270 bp) and 16s rRNA (886 bp) when analysed on agarose gel (Figure 3). Multiplex PCR result of other bacterial isolates is presented in Figure 4 and Figure 5. Results of our multiplex PCR were compared with microbiology laboratory results. All the uncultured specimens were correctly identified as $S$. aureus, 26 of them tested positive for mecA correlating with phenotype (Cefoxitin disc diffusion) as MRSA. This is probably the first time that multiplex PCR is being demonstrated directly on a variety of uncultured clinical specimens. 


\section{Discussion}

Thermostable nuclease gene nuc was reported to have $100 \%$ sensitivity and specificity for the identification of $S$. aureus isolate [32] [33]. A few studies have employed femA and nuc along with mecA as molecular targets for identification of $S$. aureus and characterization of MRSA [34]. Some commercial kits are available for directly detecting MRSA directly from nasal swabs and blood cultures [34] (Table 1). Several kits target orfX and sequence near to SCCmec region in the genome while one kit (BDMaxStaphSR kit, Becton Dickinson) also targets nuc in addition to $\operatorname{mec} A$ and $\operatorname{orfX}$ [35]. We reported poor sensitivity when femA was used as species identification genetic marker in PCR [23]. Therefore, we evaluated nuc as species specific marker along with mecA and 16S rRNA simultaneously to identify MRSA from methicillin resistance non- $S$. aureus species. A non- $S$. aureus methicillin resistant species is indicated when our multiplex PCR result is negative for nuc but positive for $\operatorname{mec} A$ and $16 \mathrm{~S}$ rRNA targets. Figure 4. Lane 1. exemplifies this where $S$. epidermidis does not amplify nuc sequence but only shows amplicons from $16 \mathrm{~S}$ rRNA and mecA. The

Table 3. Antibiotic Susceptibility Testing. (a) Oxacillin vs mecA-PCR ( $\mathrm{n}=157$ ); (b) Cefoxitin vs $\operatorname{mec} A-\mathrm{PCR}(\mathrm{n}=157)$.

(a)

\begin{tabular}{cccc}
\hline Oxacillin & $\begin{array}{c}\text { mec } A \\
\text { PCR } \\
(+)\end{array}$ & $\begin{array}{c}\text { mecA } \\
\text { PCR } \\
(-)\end{array}$ & Total \\
\hline$(+)$ & 70 & 3 & 73 \\
$(-)$ & 35 & 49 & 84 \\
Total & 105 & 52 & 157 \\
\hline
\end{tabular}

(b)

\begin{tabular}{cccc}
\hline Cefoxitin & $\begin{array}{c}\text { mec } A \text { PCR } \\
(+)\end{array}$ & $\begin{array}{c}\text { PCR } \\
(-)\end{array}$ & Total \\
\hline$(+)$ & 105 & 0 & 105 \\
$(-)$ & 1 & 51 & 52 \\
Total & 106 & 51 & 157 \\
\hline
\end{tabular}

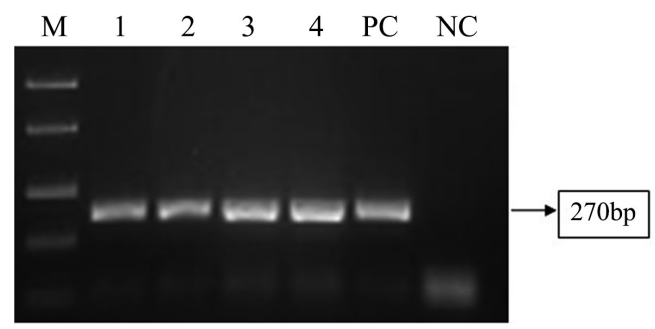

Figure 2. Results of nuc PCR. Legend: Lane M-Low range Molecular Size Ladder $100 \mathrm{bp}$, Lane 1 - 4-nuc PCR positive $S$. aureus isolates, Lane PC-positive control, Lane NCnegative control. 


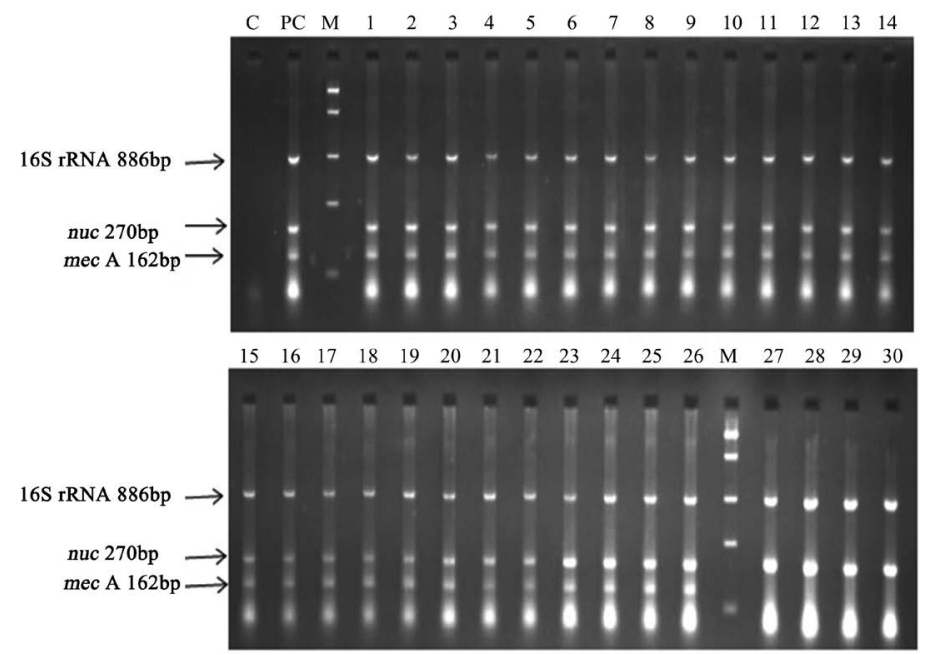

Figure 3. Multiplex PCR Analysis of Uncultured Clinical Samples. Legend: Lane CNegative Control, Lane PC-Positive Control, Lane M-Molecular Size Marker (100 bp), Lane 1-Wound Swab, Lane 2-Nasal Swab, Lane 3 \& 4-Wound Swab, Lane 5-Pus Swab, Lane 6-ET Secretion, Lane 7-Nasal Swab, Lane 8-Vaginal Swab, Lane 9-Pus Swab, Lane 10-Abcesses, Lane 11-Fluid, Lane 12-Pus Swab, Lane 13-MRSA Screen, Lane 14-Wound Swab, Lane 15-ET Secretion, Lane 16-Vaginal Swab, Lane 17-Pus Swab, Lane 18-Wound Swab, Lane 19-MRSA Screen, Lane 20-Pus Swab, Lane 21Skin Peel, Lane 22-Pus Swab, Lane 23-Abscesses, Lane 24-Nasal Swab, Lane 25Wound Swab, Lane 26-Skin Peel Methicillin Resistant $S$. aureus Clinical Specimens, Lane M-Molecular Marker (100 bp), Lane 27 \& 28-Pus Swab, Lane 29-Nasal Swab, Lane 30-Wound Swab Methicillin Sensitive $S$. aureus Clinical Specimens.

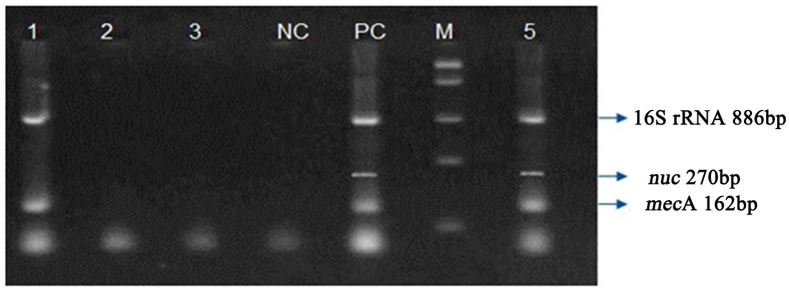

Figure 4. Multiplex PCR Analysis of Gram negative Type Strains and Uncultured Clinical Samples. Lane 1: ATCC 27626 Staphylococcus epidermidis, Lane 2: Streptococcus pnuemoniae-ATCC 6305, Lane 3: Enterococcus faecalis-ATCC 29212, Lane NC: Negative Control, lane PC: Positive Control ATCC 6538 MRSA, Lane M: Molecular marker (100 bp), Lane 5: Groin swab.

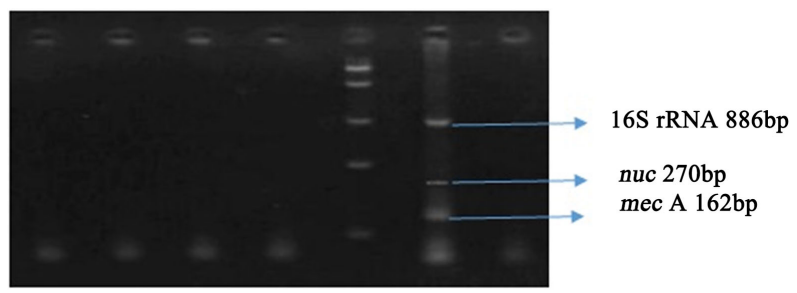

Figure 5. Testing the specificity of the Multiplex PCR. Agarose Gel analysis of analysis of non-S. aureus bacterial type strains. Lane 1: ATCC 19606-Acinetobacter baumanii, Lane 2: 10418-E. coli, Lane 3: 70060-K. pneumoniae, Lane 4: ATCC 13048-Enterobacter aerogenes, Lane M: Molecular marker, Lane PC: Positive Control ATCC 6538 MRSA, Lane NC: Negative Control. 
specificity of our multiplex PCR is further demonstrated when the DNA lysates of Streptococcus pnuemoniae-ATCC 6305, Lane 2 and Enterococcus faecalisATCC 29212, Lane 3 of Figure 4 did not show any amplicons. Out of our 30 uncultured clinical samples 2 were endotracheal secretions, which are usually known to harbor mixed microbial populations. Our protocol worked with these endotracheal secretions also and identified correctly the pathogen as $S$. aureus. We first wanted to demonstrate that our protocol works well with uncultured clinical specimen with results comparable to conventional microbiology. Our intention was to show that adopting such a protocol would enable same day reporting $(6-8 \mathrm{~h})$ of MRSA status of a given sample to the clinician thus facilitating a quick therapeutic decision making. Our protocol requires an extensive evaluation and validation to determine the diagnostic sensitivity, specificity and predictive values which are in progress.

\section{Acknowledgements}

Rosy $\mathrm{CH}$ acknowledges the senior research fellowship awarded by Indian Council of Medical Research (80/797/2013). The authors also gratefully acknowledge the help of Clinical Microbiology Department for providing us the left-over clinical specimen for evaluation of our multiplex PCR method.

\section{Conflicts of Interest}

The authors declare no conflicts of interest regarding the publication of this paper.

\section{References}

[1] Bhutia, K.O., Singh, T.S., Biswas, S. and Adhikari, L. (2012) Evaluation of Phenotypic with Genotypic Methods for Species Identification and Detection of Methicillin Resistant in Staphylococcus aureus. International Journal of Applied and Basic Medical Research, 2, 84-91. https://doi.org/10.4103/2229-516X.106348

[2] Sahebnasagh, R., Saderi, H. and Owlia, P. (2014) The Prevalence of Resistance to Methicillin in Staphylococcus aureus Strains Isolated from Patients by PCR Method for Detection of mecA and nuc Genes. Iranian Journal of Public Health, 43, 84-92.

[3] Gleghorn, K.G.E. and Kelly, E.K. (2015) New Antibiotics in the Management of Acute Bacterial Skin and Skin Structure Infections. Skin Therapy Letter, 20, 7-9.

[4] Martineau, F., Picard, F.J., Roy, P.H., Ouellette, M. and Bergeron, M.G. (1998) Species-Specific and Ubiquitous-DNA-Based Assays for Rapid Identification of Staphylococcus aureus. Journal of Clinical Microbiology, 36, 618-623.

[5] Menichetti, F. (2008) Current and Emerging Serious Gram-Positive Infections. Clinical Microbiology and Infection, 11, 22-28. https://doi.org/10.1111/j.1469-0691.2005.01138.x

[6] Bello, C.S.S. and Qahtani, A. (2005) Pitfalls in the Routine Diagnosis of Staphylococcus aureus. African Journal of Biotechnology, 4, 83-86.

[7] Winn, C., Washington, A.S., Janda, W.M., Koneman, E.W., Schreckenberger, P.C., Procorp, G.W. and Woods, G.L. (1997) Color Atlas and Textbook of Diagnostic Microbiology. Philadelphia. 
[8] Mugalu, J., Nakakeeto, M.K., Kiguli, S. and Kaddu-Mulindwa, D.H. (2006) Aetiology, Risk Factors and Immediate Outcome of Bacteriologically Confirmed Neonatal Septicaemia in Mulago Hospital, Uganda. African Health Sciences, 6, 120-126.

[9] Becker, K., Heilmann, C. and Peters, G. (2014) Coagulase-Negative Staphylococci. Clinical Microbiology Reviews, 27, 870-926.

[10] Krishnamoorthy, P. (2016) Coagulase Negative Staphylococcal Species Mastitis: An Overview. Research Journal of Veterinary Sciences, 9, 1-10.

[11] Hovelius, B. and Mardh, P.A. (1984) Staphylococcus saprophyticus as a Common Cause of Urinary Tract Infections. Reviews of Infectious Diseases, 6, 328-337.

[12] Kawamura, Y., Hou, X.G., Sultana, F., Hirose, K., Miyake, M., Shu, S.E., et al. (1998) Distribution of Staphylococcus species among Human Clinical Specimens and Emended Description of Staphylococcus caprae. Journal of Clinical Microbiology, 36, 2038-2042.

[13] Shittu, A., Lin, J., Morrison, D. and Kolawole, D. (2006) Identification and Molecular Characterization of Mannitol Salt Positive, Coagulase-Negative Staphylococci from Nasal Samples of Medical Personnel and Students. Journal of Medical Microbiology, 55, 317-324.

[14] Kateete, D.P., Kimani, C.N., Katabazi, F.A., Okeng, A., Okee, M.S., Nanteza, A., et al. (2010) Identification of Staphylococcus aureus. DNase and Mannitol Salt Agar Improve the Efficiency of the Tube Coagulase Test. Annals of Clinical Microbiology and Antimicrobials, 9, 23. https://doi.org/10.1186/1476-0711-9-23

[15] Koneman, E.W., et al. (2006) Color Atlas \& Textbook of Diagnostic Microbiology. 6th Edition, Lippin-cott-Raven Koneman EW, Philadelphia, 551-576.

[16] Varaldo, P.E., et al. (1998) Staphylococcus delphini sp. nov. a Coagulase-Positive Species Isolated from Dolphins. International Journal of Bacteriology, 38, 436-439. https://doi.org/10.1099/00207713-38-4-436

[17] Vandenesch, F., Lebeau, C., Bes, M., Lina, G., Lina, B., Greenland, T., et al. (1994) Clotting Activity in Staphylococcus schleiferi Subspecies from Human Patients. Journal of Clinical Microbiology, 32, 388-392.

[18] Fomda, B.A., Thokar, M.A., Bashir, G., Khan, A., Kour, A., Zahoor, D., et al. (2014) Prevalence and Genotypic Relatedness of Methicillin Resistant Staphylococcus aureus in a Tertiary Care Hospital. Journal of Postgraduate Medicine, 60, 386-389. https://doi.org/10.4103/0022-3859.143964

[19] Kobayashi, N., Wu, H., Kojima, K., Taniguchi, K., Urasawa, S., Uehara, N., et al. (1994) Detection of mecA, femA, and femB Genes in Clinical Strains of Staphylococci Using Polymerase Chain Reaction. Epidemiology \& Infection, 113, 259-266. https://doi.org/10.1017/S0950268800051682

[20] Vannuffel, P., Laterre, P.F., Bouyer, M., Gigi, J., Vandercam, B., Reynaert, M., et al. (1998) Rapid and Specific Molecular Identification of Methicillin-Resistant Staphylococcus aureus in Endotracheal Aspirates from Mechanically Ventilated Patients. Journal of Clinical Microbiology, 36, 2366-2368.

[21] Mohanasoundaram, K.M. and Lalitha, M.K. (2008) Comparison of Phenotypic Versus Genotypic Methods in the Detection of Methicillin Resistance in Staphylococcus aureus. Indian Journal of Medical Research, 127, 78-84.

[22] Kaur, H., et al. (2017) Status of Methicillin Resistant Staphylococcus aureus Infections and Evaluation of PVL Producing Strains in Belgaum, South India. Journal of Krishna Institute of Medical Sciences University, 1, 43-51.

[23] Rosy Chikkala, K.D., Iyer, R., Ratnakar, K.S. and Sritharan, V. (2018) Panton Va- 
lentine Leukocidin (PVL) and Thermonuclease (NUC) Profile in Clinical Isolates of $S$. aureus and an Assessment of Impact of Variations in Nucleotide Sequences of fem A, B and X Genes. International Journal of Medical and Health Research, 4, 114-119.

[24] Jernigan, J.A., Titus, M.G., Groschel, D.H., Getchell-White, S. and Farr, B.M. (1996) Effectiveness of Contact Isolation during a Hospital Outbreak of Methicillin-Resistant Staphylococcus aureus. American Journal of Epidemiology, 143, 496-504. https://doi.org/10.1093/oxfordjournals.aje.a008770

[25] Boyce, J.M. and Havill, N.L. (2008) Comparison of BD GeneOhm Methicillin-Resistant Staphylococcus aureus (MRSA) PCR versus the CHROMagar MRSA Assay for Screening Patients for the Presence of MRSA Strains. Journal of Clinical Microbiology, 46, 350-351. https://doi.org/10.1128/JCM.02130-07

[26] Rossney, A.S., Herra, C.M., Brennan, G.I., Morgan, P.M. and O’Connell, B. (2008) Evaluation of the Xpert Methicillin-Resistant Staphylococcus aureus (MRSA) Assay Using the GeneXpert Real-Time PCR Platform for Rapid Detection of MRSA from Screening Specimens. Journal of Clinical Microbiology, 46, 3285-3290. https://doi.org/10.1128/JCM.02487-07

[27] Levi, K. and Towner, K.J. (2005) Rapid Detection of Methicillin-Resistant Staphylococcus aureus from Screening Enrichment Broths by Real-Time PCR. European Journal of Clinical Microbiology \& Infectious Diseases, 24, 423-427. https://doi.org/10.1007/s10096-005-1336-4

[28] Joseph Sambrook, D.W.R. (2001) Molecular Cloning-A Laboratory Manual. Cold Spring Harbor Laboratory Press, New York.

[29] Sritharan, V. and Barker, R.H. (1991) A Simple Method for Diagnosing M. tuberculosis Infection in Clinical Samples Using PCR. Molecular and Cellular Probes, 5, 385-395. https://doi.org/10.1016/S0890-8508(06)80011-3

[30] Poulsen, A.B., Skov, R. and Pallesen, L.V. (2003) Detection of Methicillin Resistance in Coagulase-Negative Staphylococci and in Staphylococci Directly from Simulated Blood Cultures Using the EVIGENE MRSA Detection Kit. Journal of Antimicrobial Chemotherapy, 51, 419-421. https://doi.org/10.1093/jac/dkg084

[31] Oliveira, D.C. and de Lencastre, H. (2002) Multiplex PCR Strategy for Rapid Identification of Structural Types and Variants of the mec Element in Methicillin-Resistant Staphylococcus aureus. Antimicrobial Agents and Chemotherapy, 46, 21552161. https://doi.org/10.1128/AAC.46.7.2155-2161.2002

[32] Brakstad, O.G. and Maeland, J.A. (1995) Direct Identification of Staphylococcus aureus in Blood Cultures by Detection of the Gene Encoding the Thermostable Nuclease or the Gene Product. APMIS, 103, 209-218. https://doi.org/10.1111/j.1699-0463.1995.tb01097.x

[33] Brakstad, O.G., Maeland, J.A. and Tveten, Y. (1993) Multiplex Polymerase Chain Reaction for Detection of Genes for Staphylococcus aureus Thermonuclease and Methicillin Resistance and Correlation with Oxacillin Resistance. APMIS, 101, 681-688. https://doi.org/10.1111/j.1699-0463.1993.tb00165.x

[34] Cho, J.I., Jung, H.J., Kim, Y.J., Park, S.H., Ha, S.D. and Kim, K.S. (2007) Detection of Methicillin Resistance in Staphylococcus aureus Isolates Using Two-Step Triplex PCR and Conventional Methods. Journal of Microbiology and Biotechnology, 17, 673-676.

[35] Belmekki, M., Mammeri, H., Hamdad, F., Rousseau, F., Canarelli, B. and Biendo, M. (2013) Comparison of Xpert MRSA/SA Nasal and MRSA/SA ELITe MGB Assays for Detection of the mecA Gene with Susceptibility Testing Methods for De- 
termination of Methicillin Resistance in Staphylococcus aureus Isolates. Journal of Clinical Microbiology, 51, 3183-3191. https://doi.org/10.1128/JCM.00860-13

[36] Desjardins, M., Guibord, C., Lalonde, B., Toye, B. and Ramotar, K. (2006) Evaluation of the IDI-MRSA Assay for Detection of Methicillin-Resistant Staphylococcus aureus from Nasal and Rectal Specimens Pooled in a Selective Broth. Journal of Clinical Microbiology, 44, 1219-1223. https://doi.org/10.1128/JCM.44.4.1219-1223.2006

[37] Wang, H.Y., Kim, S., Kim, J., Park, S.D., Uh, Y. and Lee, H. (2014) Multiplex Real-Time PCR Assay for Rapid Detection of Methicillin-Resistant Staphylococci Directly from Positive Blood Cultures. Journal of Clinical Microbiology, 52, 1911 1920. https://doi.org/10.1128/JCM.00389-14

[38] Johnson, G., Millar, M.R., Matthews, S., Skyrme, M., Marsh, P., Barringer, E., et al. (2006) Evaluation of BacLite Rapid MRSA, a Rapid Culture Based Screening Test for the Detection of Ciprofloxacin and Methicillin Resistant $S$. aureus (MRSA) from Screening Swabs. BMC Microbiology, 6, 83. https://doi.org/10.1186/1471-2180-6-83

[39] Wagenvoort, J.H., van de Cruijs, M.F., Meuwissen, C.T., Gronenschild, J.M. and De Brauwer, E.I. (2007) Comparison of an Enrichment Broth-Enhanced Commercial PCR Procedure versus Bacteriological Culture for Separating Non-Colonized from Suspected or Colonized MRSA Individuals. European Journal of Clinical Microbiology \& Infectious Diseases, 26, 155-160. https://doi.org/10.1007/s10096-007-0269-5

[40] Park, S.D., Lee, G., Wang, H.-Y., Park, M., Kim, S., Kim, H., et al. (2014) Evaluation of PCR-Reverse Blot Hybridization Assay, REBA Sepsis-ID Test, for Simultaneous Identification of Bacterial Pathogens and mecA and van Genes from Blood Culture Bottles. Annals of Laboratory Medicine, 34, 446-455.

https://doi.org/10.3343/alm.2014.34.6.446

[41] Wang, H.Y., Kim, S., Kim, J., Park, S.D., Kim, H.Y., Uh, Y., et al. (2016) Comparison of Multiplex Real-Time PCR and PCR-Reverse Blot Hybridization Assay for the Direct and Rapid Detection of Bacteria and Antibiotic Resistance Determinants in Positive Culture Bottles. Journal of Medical Microbiology, 65, 962-974. https://doi.org/10.1099/jmm.0.000319

[42] Oh, A.-C., Lee, J.K., Lee, H.N., Hong, Y.J., Chang, Y.H., Hong, S.-I., et al. (2013) Clinical Utility of the Xpert MRSA Assay for Early Detection of Methicillin-Resistant Staphylococcus aureus. Molecular Medicine Reports, 7, 11-15. https://doi.org/10.3892/mmr.2012.1121

[43] Sherlock, O., Dolan, A. and Humphreys, H. (2010) MRSA Screening: Can One Swab Be Used for Both Culture and Rapid Testing? An Evaluation of Chromogenic Culture and Subsequent Hain GenoQuick PCR Amplification/Detection. Clinical Microbiology and Infection, 16, 955-959. https://doi.org/10.1111/j.1469-0691.2009.02948.x

[44] Peterson, L.R., Liesenfeld, O., Woods, C.W., Allen, S.D., Pombo, D., Patel, P.A., et al. (2010) Multicenter Evaluation of the LightCycler Methicillin-Resistant Staphylococcus aureus (MRSA) Advanced Test as a Rapid Method for Detection of MRSA in Nasal Surveillance Swabs. Journal of Clinical Microbiology, 48, 1661-1666. https://doi.org/10.1128/JCM.00003-10

[45] Yam, W.C., Siu, G.K., Ho, P.L., Ng, T.K., Que, T.L., Yip, K.T., et al. (2013) Evaluation of the LightCycler Methicillin-Resistant Staphylococcus aureus (MRSA) Advanced Test for Detection of MRSA Nasal Colonization. Journal of Clinical Microbiology, 51, 2869-2874. https://doi.org/10.1128/JCM.00488-13

[46] Kelley, K., Cosman, A., Belgrader, P., Chapman, B., Sullivan, D.C. (2013) Detection 
of Methicillin-Resistant Staphylococcus aureus by a Duplex Droplet Digital PCR Assay. Journal of Clinical Microbiology, 51, 2033-2039. https://doi.org/10.1128/JCM.00196-13

[47] Ellem, J.A., Olma, T. and O’Sullivan, M.V. (2015) Rapid Detection of Methicillin-Resistant Staphylococcus aureus and Methicillin-Susceptible $S$. aureus Directly from Positive Blood Cultures by Use of the BD Max StaphSR Assay. Journal of Clinical Microbiology, 53, 3900-3904. https://doi.org/10.1128/JCM.02155-15

[48] Silbert, S., Gostnell, A., Kubasek, C. and Widen, R. (2017) Evaluation of the BD Max StaphSR Assay for Detecting Methicillin-Resistant Staphylococcus aureus (MRSA) and Methicillin-Susceptible $S$. aureus (MSSA) in ESwab-Collected Wound Samples. Journal of Clinical Microbiology, 55, 2865-2867.

https://doi.org/10.1128/JCM.00641-17

[49] Hassan, H. and Shorman, M. (2011) Evaluation of the BD GeneOhm MRSA and VanR Assays as a Rapid Screening Tool for Detection of Methicillin-Resistant Staphylococcus aureus and Vancomycin-Resistant Enterococci in a Tertiary Hospital in Saudi Arabia. International Journal of Microbiology, 2011, Article ID: 861514. https://doi.org/10.1155/2011/861514

[50] Lucke, K., Hombach, M., Hug, M. and Pfyffer, G.E. (2010) Rapid Detection of Methicillin-Resistant Staphylococcus aureus (MRSA) in Diverse Clinical Specimens by the BD GeneOhm MRSA Assay and Comparison with Culture. Journal of Clinical Microbiology, 48, 981-984. https://doi.org/10.1128/JCM.01990-09

[51] Reischl, U., Linde, H.J., Metz, M., Leppmeier, B. and Lehn, N. (2000) Rapid Identification of Methicillin-Resistant Staphylococcus aureus and Simultaneous Species Confirmation Using Real-Time Fluorescence PCR. Journal of Clinical Microbiology, 38, 2429-2433. 